\title{
Molecular basis of androgen insensitivity
}

\author{
Albert Brinkmann,* Guido Jenster,* Carrie Ris-Stalpers,* Hetty van der Korput, $\dagger$ \\ Hennie Brüggenwirth,* Annemie Boehmer,* and Jan Trapman $\dagger$
}

\author{
*Department of Endocrinology and Reproduction; and †Department of Pathology, Erasmus \\ University Rotterdam, Rotterdam, The Netherlands
}

\begin{abstract}
Male sexual differentiation and development proceed under direct control of androgens. Androgen action is mediated by the intracellular androgen receptor, which belongs to the superfamily of ligand-dependent transcription factors. In the X-linked androgen insensitivity syndrome, defects in the androgen receptor gene have prevented the normal development of both internal and external male structures in 46,XY individuals. The complete form of androgen insensitivity syndrome is characterized by 46,XY karyotype, external female phenotype, intra-abdominal testes, absence of uterus and ovaries, blindly ending vagina, and gynecomastia. There is also a group of disorders of androgen action that result from partial impairment of androgen receptor function. Clinical indications can be abnormal sexual development of individuals with a predominant male phenotype with severe hypospadias and micropenis or of individuals with a predominantly female phenotype with cliteromegaly, ambiguous genitalia, and gynecomastia. Complete or gross deletions of the androgen receptor gene have not been frequently found in persons with the complete androgen insensitivity syndrome, whereas point mutations at several different sites in exons 2-8 encoding the DNA- and androgen-binding domain have been reported in both partial and complete forms of androgen insensitivity, with a relatively high number of mutations in two clusters in exons 5 and 7. The number of mutations in exon 1 is extremely low, and no mutations have been reported in the hinge region, located between the DNA-binding domain and the ligand-binding domain. The X-linked condition of spinal and bulbar muscle atrophy (Kennedy's disease) is characterized by a progressive motor neuron degeneration associated with signs of androgen insensitivity and infertility. The molecular cause of spinal and bulbar muscle atrophy is an expanded length ( $>40$ residues) of one of the polyglutamine stretches in the $N$-terminal domain of the androgen receptor. (Steroids 61:172-175, 1996)
\end{abstract}

Keywords: androgen; androgen receptor; mutation; androgen insensitivity; hormone receptor

\section{Introduction}

Androgens (testosterone and $5 \alpha$-dihydrotestosterone) play a crucial role in various stages of male development ${ }^{1}$ by interacting in their target cells with androgen receptors to regulate gene expression. The androgen receptor belongs to a large family of DNA-binding zinc-finger proteins, which also includes the other steroid hormone receptors, thyroid hormone receptors, retinoid receptors, and an increasing number of orphan receptors. ${ }^{2}$ During male sexual differentiation specific roles are played by testosterone and $5 \alpha$ dihydrotestosterone. Initially testosterone is the active hor-

Address reprint requests to Dr. A.O. Brinkmann, Department of Endocrinology and Reproduction, Erasmus University Rotterdam, PO Box 1738, 3000 DR Rotterdam, The Netherlands. mone with respect to development of the Wolffian ductderived structures such as epididymis, vas deferens, seminal vesicles, and the ejaculatory duct. In contrast with the development of the Wolffian ducts, masculinization of the external genitalia and the development of the urogenital sinus into the urethra and the prostate require the action of $5 \alpha$-dihydrotestosterone. $5 \alpha$-Dihydrotestosterone is actively formed from testosterone by the steroid $5 \alpha$-reductase type 2 enzyme, which is specifically expressed in the urogenital sinus and urogenital tubercle. ${ }^{1}$

In the X-linked androgen insensitivity syndrome, defects in the androgen receptor gene prevent the normal development of both internal and external male structures in 46,XY individuals. The rare $\mathrm{X}$-linked condition of spinal and bulbar muscular atrophy is characterized by a progressive degeneration of motor neurons and is sometimes associated with signs of androgen insensitivity and infertility. 
Molecular basis of androgen insensitivity: Brinkmann et al.

Cloning and characterization of cDNA encoding the human androgen receptor and the elucidation of the organization of the human androgen receptor gene have greatly increased our knowledge of the molecular structure of the human androgen receptor protein. ${ }^{3-6}$ The gene is located on the X-chromosome and encompasses $>90$ kilobases (7-9) with the protein coding region divided over eight exons. The sequence encoding the $\mathrm{N}$-terminal domain is represented by one large exon (exon 1), the DNA-binding domain is encoded by exons 2 and 3 , and the information for the steroidbinding domain distributed over five exons (exons 4-8). The N-terminal domain of the human androgen receptor is characterized by the presence of several homopolymeric amino acid stretches. ${ }^{10}$

The hormone-binding domain is constituted by approximately 250 amino acid residues in the C-terminal region. The human androgen receptor is functionally active without the hormone-binding domain in that deletion of this domain leads to a constitutively active androgen receptor protein, with wild type trans-activation capacity in the absence of hormone. ${ }^{11}$ In contrast, almost the entire $\mathrm{N}$-terminal domain is necessary for full transcriptional activity. ${ }^{12}$

The human androgen receptor is a phosphoprotein and is additionally phosphorylated upon hormone binding. ${ }^{13}$ Phosphorylation of the androgen receptor occurs mainly in a region spanning the first 300 amino acid residues, located in the N-terminal transactivation domain, and only serine residues have been found to be phosphorylated. ${ }^{14,15}$

\section{Androgen receptor abnormalities}

In this overview we will focus on the molecular structure of the androgen receptor in subjects with the androgen insensitivity syndrome and in patients with Kennedy's syndrome (X-linked spinal and bulbar muscular atrophy). Throughout the text, the numbering of the different codons is based on a total number of 910 amino acid residues in the human androgen receptor ( 20 glutamine and 16 glycine residues).

\section{Androgen receptor abnormalities in the androgen insensitivity syndrome}

Only a few cases have been reported with partial or complete deletion of the androgen receptor gene, indicating the relative low frequency of this type of androgen receptor defect. ${ }^{16-18}$ Most individuals in the reported cases are completely androgen resistant. There has been no report of possible mutations in the androgen receptor promoter region or in the $5^{\prime}$ - and $3^{\prime}$-untranslated regions of the gene.

We have detected a single nucleotide insertion (codon 42, C insertion) and a single nucleotide deletion (codon 263, A deletion) in exon 1 in individuals with the complete androgen insensitivity syndrome (Figure 1). Both mutations caused frameshifts resulting in premature stop codons at positions 171 and 292, respectively. In both cases androgen receptor protein expression was undetectable. Another mutation in exon 1 results in a premature stop codon at position 493.

\section{Mutations in the DNA-binding domain}

In total 24 different mutations in the DNA-binding domain (exons 2 and 3 ) have been published ${ }^{17,18}$ (Figure 2). Eleven

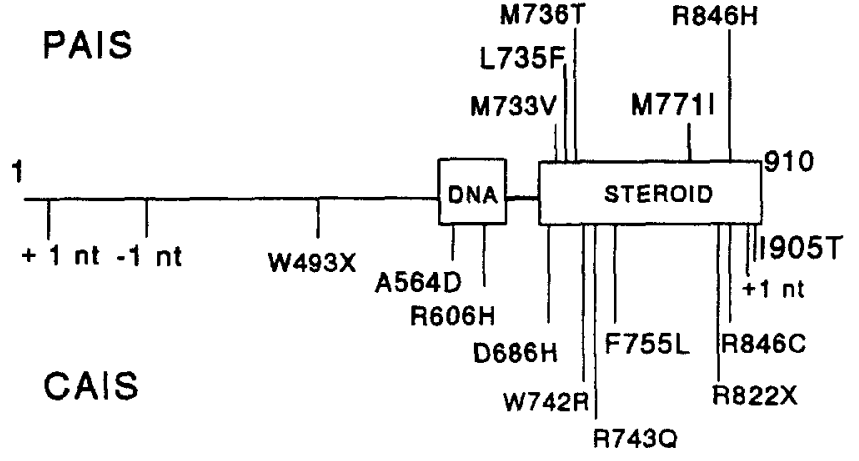

Figure 1 Schematic representation of the localization of androgen receptor mutations detected in Rotterdam in patients with the complete (CAIS) and partial (PAIS) form of androgen insensitivity. Amino acid residues are indicated as one-letter symbols. nt, nucleotide.

mutations were observed in the first zinc cluster and thirteen in the second zinc cluster.

In genital skin fibroblasts from a subject with a severe form of the X-linked Reifenstein syndrome (partial androgen insensitivity) we detected differential pre-mRNA splicing due to a genomic deletion involving the intron 2 branch point ${ }^{19}$ and resulting in $92 \%$ aberrant splicing of wild-type transcript. The mutant transcript encodes an androgen receptor protein lacking the second zinc finger of the DNAbinding domain, is unable to activate transcription, and does not influence the transactivating properties of the wild-type androgen receptor. A complete deletion of exon three has also been reported in a patient with complete androgen insensitivity. ${ }^{16-18}$

\section{Mutations in the androgen-binding domain}

Several functional and structural aspects have been ascribed to exon 4 , which harbors part of a highly conserved nucleoplasmin like nuclear localization signal, the hinge region, and part of the steroid-binding domain. ${ }^{20}$ Therefore, mutations in exon 4 could affect different functions of the androgen receptor. All reported mutations to date in exon 4 are located in the part of the exon that encodes the $\mathrm{N}$-terminal region of the steroid-binding domain. In one patient with the complete form of androgen insensitivity we have detected a $G$ to $T$ mutation on position 1 in the splice donor site of intron $4,{ }^{21}$ leading to abnormal androgen receptor mRNA splicing. The mutant receptor was unable to bind androgens and did not activate transcription of an androgen-regulated reporter gene construct. ${ }^{21}$ In two unrelated individuals with the complete form of androgen insensitivity we have found two different point mutations at the same nucleotide in codon 686 (aspartic acid) of exon $4^{22}$ (Figure 1). Both mutant androgen receptors displayed the same altered binding characteristics and were devoid of transactivation activity in the presence of physiological hormone concentrations. ${ }^{22}$

Exon 5 forms an essential part of the steroid-binding domain of the androgen receptor. We have detected five different mutations in exon 5 , of which the M733V and M736T mutations were found in patients with the partial form of the androgen insensitivity syndrome (Figure 1). In 


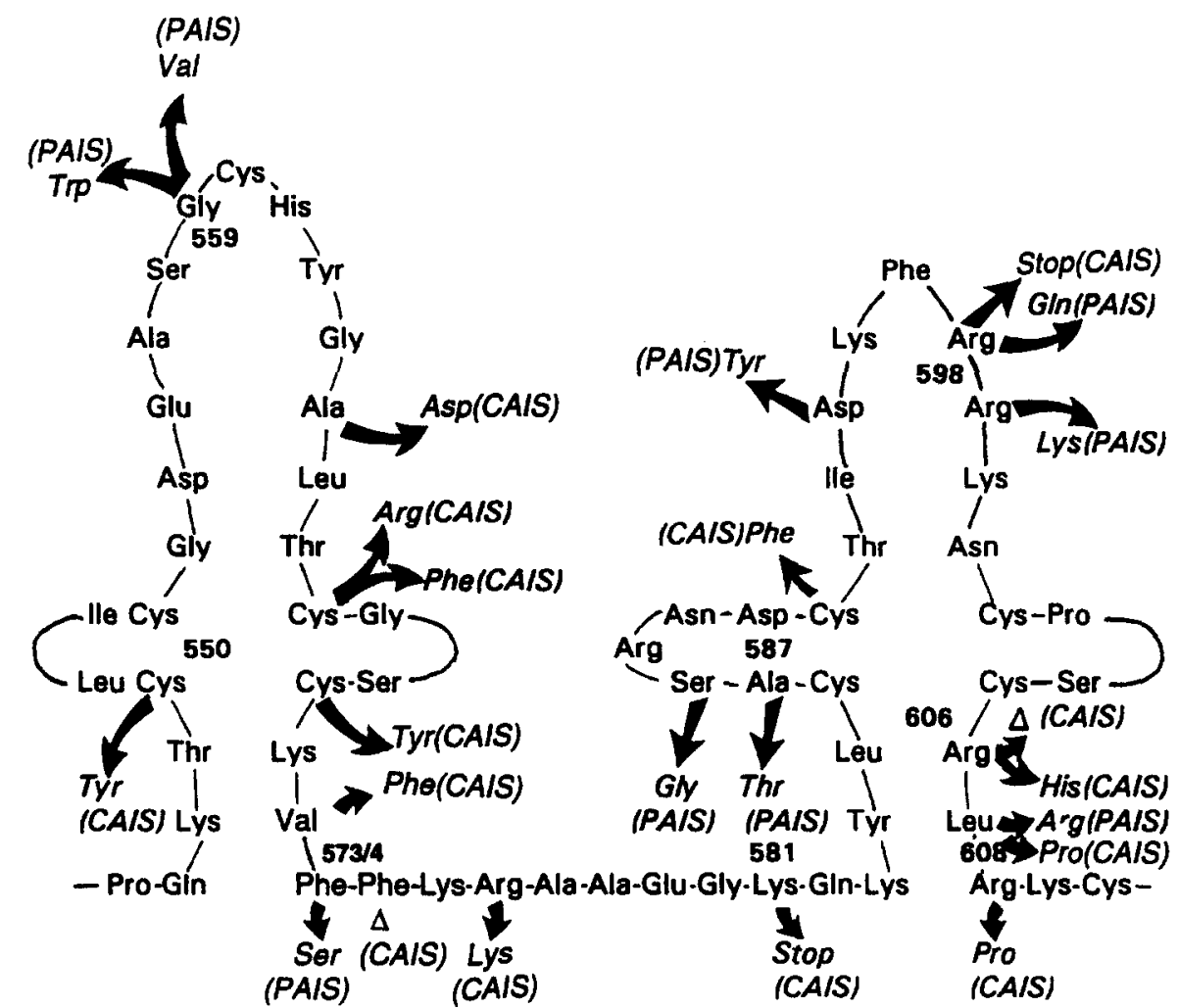

Figure 2 Location of the different amino acid substitutions in the DNA-binding domain due to point mutations in exons 2 and 3 and two deletions of a codon in the androgen receptor gene of individuals with complete (CAIS) or partial (PAIS) androgen insensitivity. ${ }^{17,18}$ Amino acid residues are indicated as three-letter symbols.

exon 5 a total of 33 point mutations in 20 different codons has been reported ${ }^{17,18}$ (unpublished observations; Figure 1). Two clusters of mutations are localized in exon 5 between codons 723-732 and 740-757 in the androgen receptor gene of patients with the complete androgen insensitivity syndrome. We have found three mutations (W742R; R743Q; F755L) located in the second cluster (Figure 1).

The twelve reported mutations in exon 6 in eleven different codons have been found in androgen-insensitive individuals with the complete form (7 instances) and the partial form ( 5 instances) of the syndrome. ${ }^{17,18}$

For exon 7, thirteen mutations in eight different codons have been reported in patients with the complete androgen insensitivity syndrome, and seven mutations in patients with partial androgen insensitivity ${ }^{17,18}$ (unpublished observations; Figure 1). In addition in a patient with the complete syndrome we have found an insertion of one nucleotide in codon 839 causing a frameshift and resulting in a premature stop codon (Figure 1). From mutational analysis studies it is known that this kind of receptor truncation completely abolishes hormone binding and transcriptional activity. ${ }^{1}$

In total thirteen mutations in exon 8 have been reported. Eight mutations were found in subjects with the complete form of androgen insensitivity and five in subjects with the partial form ${ }^{17,18}$ (unpublished observations; Figure 1).

\section{Androgen receptor abnormalities in spinal and bulbar muscular atrophy}

An unique example of tissue-specific effects of a defective androgen receptor is Kennedy's syndrome. This rare, X- linked motor neuron disease becomes manifest in men between the age of 30 and 50 and is characterized by a progressive spinal and bulbar muscular atrophy associated with signs of androgen insensitivity and infertility. ${ }^{23-25}$ The length of the polyglutamine stretch in the androgen receptor in all investigated Kennedy's syndrome patients ranges between 40 and $62 .^{26}$

We have investigated the effect of an expanded polyglutamine stretch and also a completely deleted glutamine stretch on the transactivation function of the androgen receptor in a model system. For this purpose the androgen receptor constructs were expressed after cotransfection of COS cells with a reporter gene construct containing either the mouse mammary tumor virus promoter or the prostatespecific antigen (PSA) promoter. ${ }^{27}$ In these experiments a 2 -fold reduction in transcription activation was observed with both reporter constructs and the androgen receptor with 48 glutamine residues. Complete deletion of the glutamine stretch resulted in a significant increase in transcriptional regulation only with the PSA reporter construct. ${ }^{28}$ The differences could not be explained by differences in the level of receptor protein expression. In similar studies Mhatre et al. ${ }^{29}$ also found that an androgen receptor with an expanded polyglutamine stretch transactivates subnormally. Whether doubling of the length of the polyglutamine stretch directly affects motor neuron function is still unclear; it is possible that a change in the structural constraints on the $\mathrm{N}$-terminal domain could result in a modified interaction with motor neuron-specific transcription factors and consequently in an altered assembly of the transcription initiation complex. ${ }^{30}$ 
In conclusion, at least two pathological situations are associated with androgen resistance due to abnormal androgen receptor structure and function: androgen insensitivity syndrome and spinal and bulbar muscular atrophy. These in vivo situations provide the opportunity to correlate receptor alterations with impairment of its physiological function, which may add new perspectives to our understanding of the role of the androgen receptor in androgen action.

\section{Acknowledgments}

We thank T. Hoogenboezem, M.C.T. Verleun-Mooijman, P.E. de Ruiter, and E. Kamst for excellent technical assistance. These studies were supported by the Netherlands Organization for Scientific Research (NWO), by the Sophia Foundation for Medical Research, and by the Dutch Cancer Society.

\section{References}

1. Griffin JE, McPhaul MJ, Russell DW, Wilson JD (1995). The androgen resistance syndromes: steroid $5 \alpha$-reductase 2 deficiency, testicular feminization and related disorders. In: Scriver CR, Baudet AL, Sly WL, Valle D (eds), The Metabolic and Molecular Basis of Inherited Disease, McGraw-Hill, New York, Ed. 7, Vol. II, pp. 2967-2998

2. Tsai MJ, O'Malley BW (1994). Molecular mechanisms of action of steroid/thyroid receptor superfamily members. Ann Rev Biochem 63:451-486.

3. Chang C, Kokontis J, Liao S (1988). Structural analysis of complementary DNA and amino acid sequences of human and rat androgen receptors. Proc Natl Acad Sci USA 85:7211-7215.

4. Lubahn DB, Joseph DR, Sar M, Tan J, Higgs HN, Larson RE, French FS, Wilson EM (1988). The human androgen receptor: complementary deoxyribonucleic acid cloning, sequence analysis and gene expression in prostate. Mol Endocrinol 2:1265-1275.

5. Trapman J, Klaassen P, Kuiper GGJM, van der Korput JAGM, Faber PW, van Rooij HCJ, Geurts van Kessel A, Voorhorst MM, Mulder E, Brinkmann AO (1988). Cloning, structure and expression of a cDNA encoding the human androgen receptor. Biochem Biophys Res Commun 153:241-248.

6. Tilley WD, Marcelli M, Wilson JD, McPhaul MJ (1989). Characterization and expression of a cDNA encoding the human androgen receptor. Proc Natl Acad Sci USA 86:327-331.

7. Kuiper GGJM, Faber PW, van Rooij HCJ, van der Korput JAGM, Ris-Stalpers C, Klaassen P, Trapman J, Brinkmann AO (1989). Structural organization of the human androgen receptor gene. $J \mathrm{Mol}$ Endocrinol 2:R1-R4.

8. Lubahn DB, Brown TR, Simental JA, Higgs HN, Migeon CJ, Wilson EM, French FS (1989). Sequence of the intron/exon junctions of the coding region of the human androgen receptor gene and identification of a point mutation in a family with complete androgen insensitivity. Proc Natl Acad Sci USA 86:9534-9538.

9. Marcelli M, Tilley WD, Wilson CM, Griffin JE, Wilson JD, McPhaul MJ (1990). Definition of the human androgen receptor gene structure permits the identification of mutations that cause androgen resistance: premature termination of the receptor protein at amino acid residue 588 causes complete androgen resistance. $\mathrm{Mol}$ Endocrinol 4:1105-1116.

10. Faber PW, Kuiper GGJM, van Rooij HCJ, van der Korput JAGM, Brinkmann AO, Trapman J (1989). The N-terminal domain of the human androgen receptor is encoded by one, large exon. Mol Cell Endocrinol 61:257-262.

11. Jenster $G$, van der Korput JAGM, van Vroonhoven $C$, van der Kwast TH, Trapman J, Brinkmann AO (1991). Domains of the human androgen receptor involved in steroid-binding, transcriptional activation and subcellular localization. Mol Endocrinol 5: 1396-1404

12. Jenster G, van der Korput HAGM, Trapman J, Brinkmann AO (1995). Identification of two transcription activation units in the
N-terminal domain of the human androgen receptor. $J$ Biol Chem 270:7341-7346

13. Van Laar JH, Berrevoets CA, Trapman J, Zegers ND, Brinkmann AO (1991). Hormone-dependent androgen receptor phosphorylation is accompanied by receptor transformation in human lymph node carcinoma of the prostate cells. $J$ Biol Chem 266:3734-3738.

14. Kuiper GGJM, De Ruiter PE, Trapman J, Boersma WJA, Grootegoed JA, Brinkmann AO (1993). Localization and hormonal stimulation of phosphorylation sites in the LNCaP-cell androgen receptor. Biochem J 291:95-101.

15. Kuiper GGJM, Brinkmann AO (1995). Phosphotryptic peptide analysis of the human androgen receptor: detection of a hormoneinduced phosphopeptide. Biochemistry 34:1851-1857.

16. French FS, Lubahn DB, Brown TR, Simental JA, Quigley CA, Yarbrough WG, Tan J, Sar M, Joseph DR, Evans BAJ, Hughes IA, Migeon CJ, Wilson EM (1990). Molecular basis of androgen insensitivity. Rec Progr Horm Res 46: $1-42$.

17. Quigley CA, De Bellis A, Marschke KB, El-Awady MK, Wilson EM, French FS (1995). Androgen receptor defects: historical, clinical, and molecular perspectives. Endocr Rev 16:271-321.

18. Patterson MN, Hughes IA, Gottlieb B, Pinsky L (1994). The androgen receptor gene mutations database 22:3560-3562.

19. Ris-Stalpers C, Verleun-Mooijman MCT, De Blaeij TJP, Degenhart HJ, Trapman J, Brinkmann AO (1994). Differential splicing of human androgen receptor pre-mRNA in X-linked Reifenstein syndrome, because of a deletion involving a putative branch site. Am $J$ Hum Genet 54:609-617.

20. Jenster G, Trapman J, Brinkmann AO (1993). Nuclear import of the human androgen receptor. Biochem $J$ 293:761-768.

21. Ris-Stalpers C, Kuiper GGJM, Faber PW, Schweikert HU, van Rooij HCJ, Zegers ND, Hodgins MB, Degenhart HJ, Trapman J, Brinkmann AO (1990). Aberrant splicing of androgen receptor mRNA results in synthesis of a nonfunctional receptor protein in a patient with androgen insensitivity. Proc Natl Acad Sci USA 87: 7866-7870

22. Ris-Stalpers C, Trifiro MA, Kuiper GGJM, Jenster G, Romalo G, Sai T, van Rooij HCJ, Kaufman M, Rosenfield RL, Liao S, Schweikert H-U, Trapman J, Pinsky L, Brinkmann AO (1991). Substitution of aspartic acid 686 by histidine or asparagine in the human androgen receptor leads to a functionally inactive protein with altered hormone-binding characteristics. Mol Endocrinol 5:15621569.

23. Kennedy WR, Alter M, Sung JH (1968). Progressive proximal spinal and bulbar muscular atrophy of late onset: a sex-linked recessive trait. Neurology 18:671-680.

24. Arbizu T, Santamaria J, Gomez JM, Quilez A, Serra JP (1983). A family with adult spinal and bulbar muscular atrophy, $X$-linked inheritance and associated testicular failure. J Neurological Sci 59: 371-382.

25. Warner CL, Griffin JE, Wilson JD, Jacobs LD, Murray KR, Fischbeck KH, Dickoff D, Griggs RC (1992). X-linked spinomuscular atrophy: a kindred with associated abnormal androgen receptor binding. Neurology 42:2181-2184.

26. Brooks BP, Fischbeck KH (1995). Spinal and bulbar muscular atrophy: a trinucleotide-repeat expansion neurodegenerative disease. Trends Neurosci 18:459-461.

27. Riegman PH, Vlietstra RJ, Van der Korput JAGM, Brinkmann AO, Trapman J (1991). The promoter of the prostate-specific antigen gene contains a functional androgen responsive element. Mol Endocrinol 5:1921-1930.

28. Jenster G, De Ruiter PE, Van der Korput HAGM, Kuiper GGJM, Trapman J, Brinkmann AO (1994). Changes in abundance of androgen receptor isotypes: effects of ligand treatment, glutaminestretch variation, and mutation of putative phosphorylation sites. Biochemistry 33:14064-14072.

29. Mhatre AN, Trifiro MA, Kaufman M, Kazemi-Esfarjani P, Figlewicz D, Rouleau G, Pinsky L (1993). Reduced transcriptional regulatory competence of the androgen receptor in X-linked spinal and bulbar muscular atrophy. Nature Genet 5:184-188.

30. Kazemi-Esfarjani P, Trifiro MA, Pinsky L (1995). Evidence for a repressive function of the long polyglutamine tract in the human androgen receptor: possible pathogenetic relevance for the (CAG) $n_{n^{-}}$ expanded neuronopathies. Hum Mol Genetics 4:523-527. 